(1)

\title{
U.S. Geological Survey National Water Census: Colorado River Basin Geographic Focus Area Study
}

The U.S. Geological Survey's (USGS) concept of a national census (or accounting) of water resources has evolved over the last several decades as the Nation has experienced increasing concern over water availability for multiple competing uses. The implementation of a USGS National Water Census was described in the USGS 2007 science strategy document (U.S. Geological Survey, 2007) that identified the highest priority science topics for the decade 2007-17. In 2009, the SECURE Water Act (Public Law 111-11, subtitle F) authorized the USGS to create a Water Availability and Use Assessment Program for the Nation, and in 2012, the Department of the Interior WaterSMART initiative provided funding to begin implementation of the USGS National Water Census (NWC).

Generally, the USGS NWC approaches water-availability assessment in terms of a "water budget" (fig. 1). The water-budget approach seeks to better quantify the inflows and outflows of water, as well as the change in storage volume, both nationally and at a regional scale and, by doing so, provides critical information to managers and stakeholders responsible for making water-availability decisions. The NWC has two primary components: Topical Studies and Geographic Focus Area Studies. Topical Studies do research on methods that can provide nationwide estimates of particular water-budget components at the subwatershed scale. Some examples of NWC Topical Studies include estimation of streamflow at ungaged locations; periodic quantification of evapotranspiration; and water use related to development of unconventional oil and gas. These efforts are planned to include additional topics in the future. Geographic Focus Area Studies (FASs) assess water availability and use within a defined geographic area, typically a surface-water drainage basin, to increase the understanding of factors affecting water availability in the region. In the FASs, local stakeholder input helps the USGS identify what components of the water budget are in most need of additional understanding or quantification. Focus Area Studies are planned as 3-year efforts and, typically, three FASs are ongoing in different parts of the country at any given time.

\section{The Colorado River Basin Geographic Focus Area Study}

The Colorado River Basin (CRB) (fig. 2) and the Delaware and Apalachicola-Chattahoochee-Flint (ACF) River Basins were selected by the Department of the Interior for the first round of FASs because of the perceived water shortages in the basins and potential conflicts over water supply and allocations. After gathering input from numerous stakeholders in the CRB, the USGS determined that surface-water resources in the basin were already being closely monitored and that the most important scientific contribution could be made by helping to improve estimates of four water-budget components: evapotranspiration losses, snowpack hydrodynamics, water-use information, and the relative importance of groundwater discharge in supporting streamflow across the basin. The purpose of this fact sheet is to provide a brief summary of the CRB FAS results as the study nears completion. Although some project results are still in the later stages of review and publication, this fact sheet provides an overall description of the work completed and cites the publications in which additional information can be found.

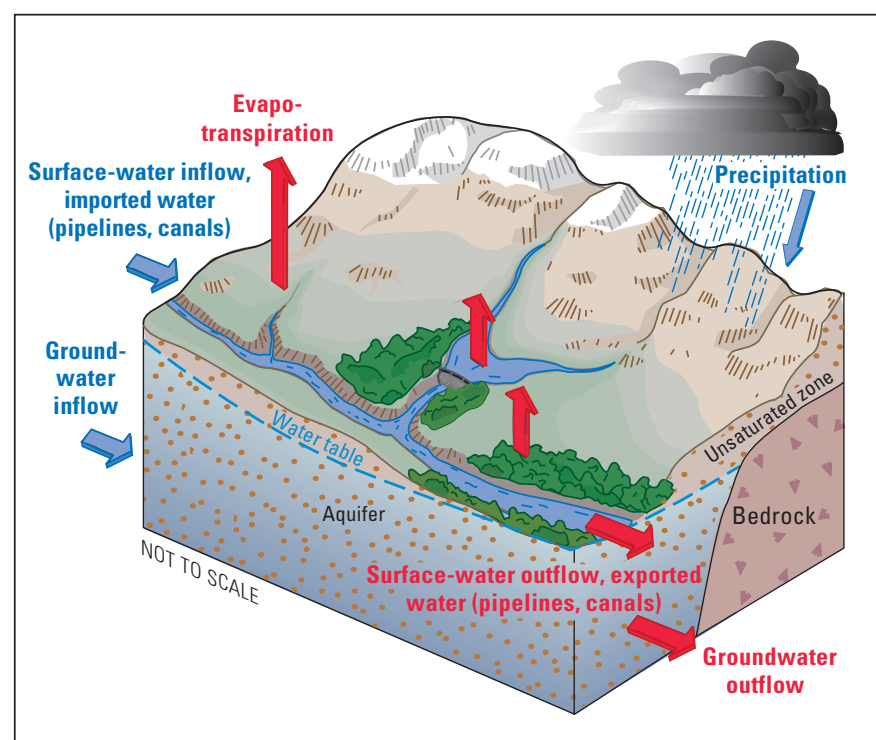

Figure 1. Components of a simple water budget for part of a watershed. Modified from Healy (2007).

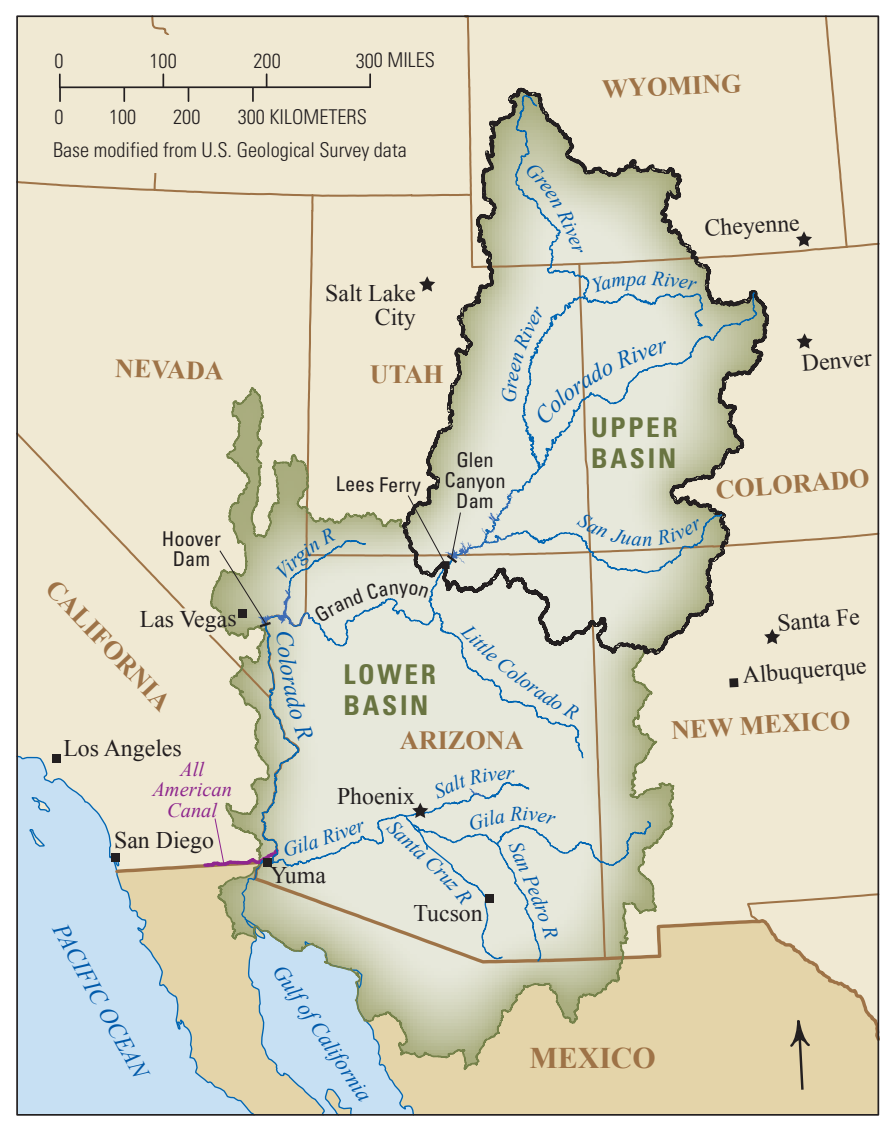

Figure 2. The Colorado River Basin. The Upper Colorado River Basin is outlined in black. 


\section{Evapotranspiration}

Evapotranspiration (ET) - the combination of water transpired from plants and water that evaporates from soil or open water bodies - is an important component of a water budget. The USGS NWC program has advanced new methods of remote-sensingbased actual ET (ETa) estimation through the development of the Operational Simplified Surface Energy Balance (SSEBop) model (Senay and others, 2013). The SSEBop ETa model uses land surface temperature (LST) derived from satellite imagery and integrates these data with local weather datasets (for example, net radiation, air temperature, humidity, wind speed, and air pressure) to produce estimates of ETa at the time of each satellite overpass. Time periods between satellite overpasses are interpolated using potential ET data derived from the land-based weather datasets.

The SSEBop ET model uses LST from both MODIS (1,000 meters $[\mathrm{m}])$ and Landsat $(100 \mathrm{~m})$ satellite sensors, thus producing estimates of ET at two spatial scales. The finer scale resolution substantially increases the computational time required to produce the estimates. Currently (2015), 1,000-m ETa estimates have been completed for the conterminous United States for the year 2000 to the present as monthly and annual totals. These datasets are archived and disseminated through the USGS Geo Data Portal at http://cida.usgs.gov/gdp/. Because of the large computational requirements, 100-m ETa estimates are produced on a region-specific basis. In 2014, the first ever CRBwide, 100-m scale ETa estimate was completed for 2010 using Landsat 5 and 7 imagery (Singh and others, 2014) followed by a 2013 CRB-wide ETa estimate using Landsat 8 (G.B. Senay, USGS, written commun., Oct. 26, 2015). These ETa estimates were validated using a combination of methods including land-based eddy-covariance flux towers, annual-scale basin water balance ET datasets (Velpuri and others, 2013), and field-reported data. The 100-m resolution ETa estimates were used by the CRB FAS to quantify agricultural irrigation consumptive water use on a field-by-field scale and are being incorporated into the irrigation category for the basinwide water-use compilation discussed in the Water-Use Information section (fig. 3).

\section{Snowpack Hydrodynamics}

Snow is an essential resource in the Western United States, providing water for drinking, irrigation, industry, energy production, and ecosystems across much of the region. In the mountains of the Western United States, most precipitation falls as snow, which accumulates in seasonal snowpacks that serve as large natural reservoirs.

Understanding the spatial distribution of snowpack water content is essential for forecasting annual snowmelt streamflow. As part of the CRB FAS, the USGS has been conducting studies of factors affecting snowpack distribution, snowmelt, and losses of snowpack water due to sublimation in the Upper Colorado River Basin (UCRB). These studies have shown that peak snowmelt in Colorado is occurring 2-3 weeks earlier than it did during the late 1970s (Clow, 2010). These changes in snowmelt timing have been traced to a combination of decreased snowfall, warm springtime air temperatures, and deposition of windblown dust onto mountain snowpacks (Clow, 2010; Painter and others, 2012; Clow and others, 2015). Also, as part of the FAS, the USGS has developed methods to make physical measurements of snowpack sublimation. Continuous measurements at multiple sites indicate a seasonal loss of 2-30 percent of annual snow water equivalent (SWE), depending on a variety of conditions including elevation, aspect, temperature, and wind speed (G. Sexstone, USGS, written commun., Nov. 19, 2015) (fig. 4).

In addition, the CRB FAS compared the output from the National Weather Service's Snow Data Assimilation (SNODAS) program (National Operational Hydrologic Remote Sensing Center. 2004) to field-based measurements at multiple locations in the CRB. The SNODAS program provides moderate-resolution model estimates of snow water content at a daily time step. The CRB FAS showed that although SNODAS performed well in forested areas, it was less accurate in areas above the tree line where snow is redistributed by wind (Clow and others, 2012). Results of these studies and ongoing work will help improve runoff forecast models used by water managers in the Western United States.

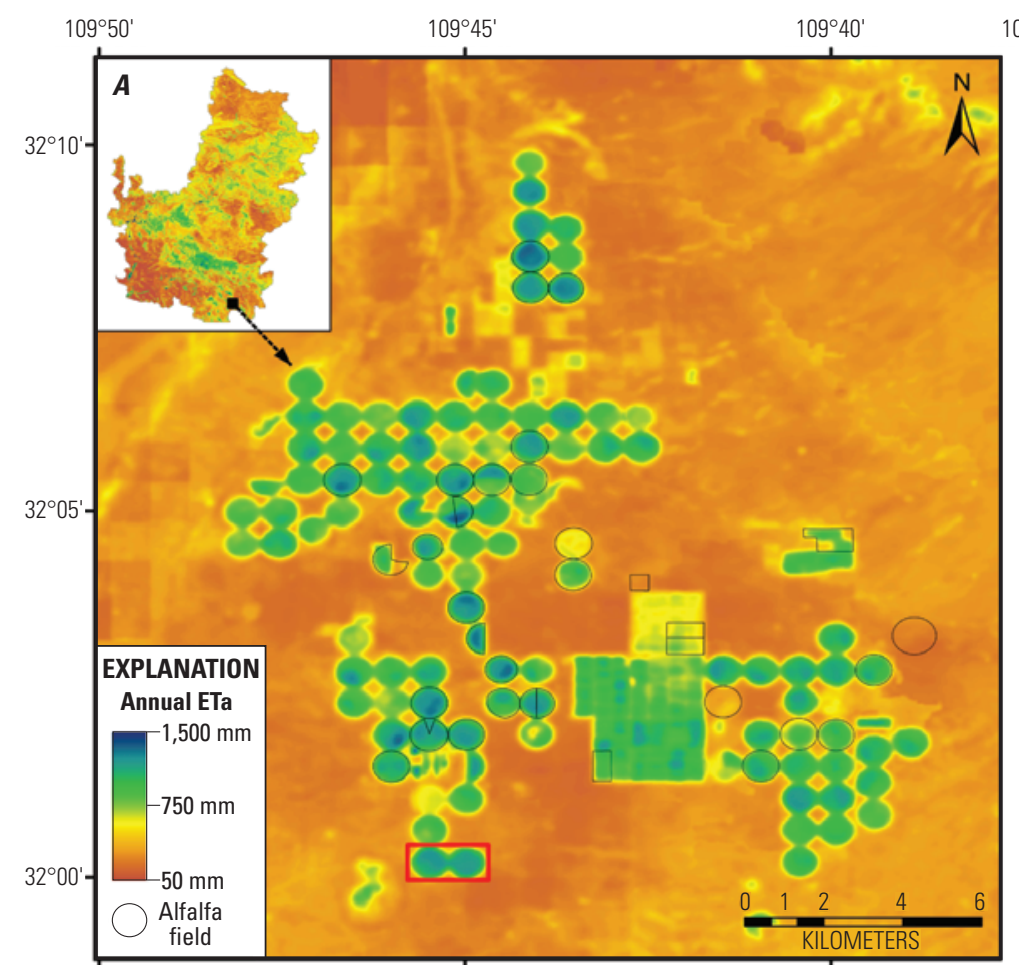

$109^{\circ} 50^{\prime}$

$109^{\circ} 45^{\prime}$

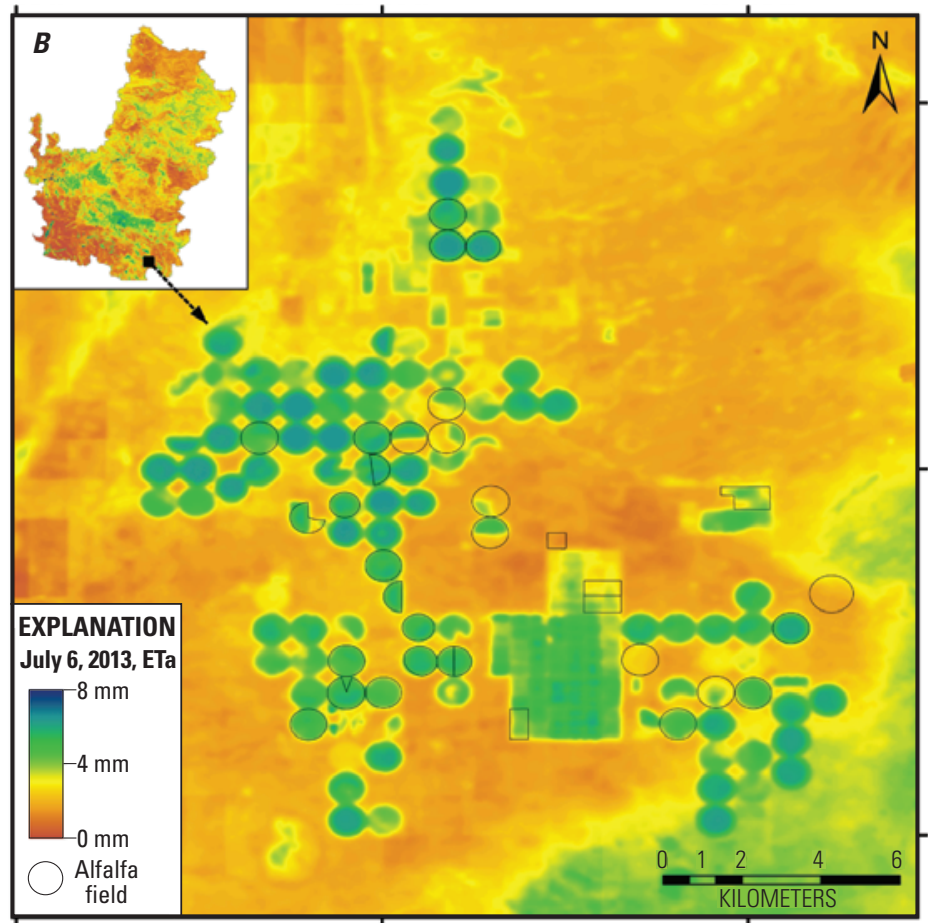

Figure 3. Zoomed-in view of the spatial distribution of $(A)$ annual evapotranspiration (millimeters per year) and $(B)$ evapotranspiration (millimeters per day) on the day of satellite overpass (July 6, 2013) in a selected part of the southern Willcox irrigation district in Arizona. Modified from G.B. Senay, USGS, written commun., Oct. 26, 2015. [ETa, actual evapotranspiration; mm, millimeter] 


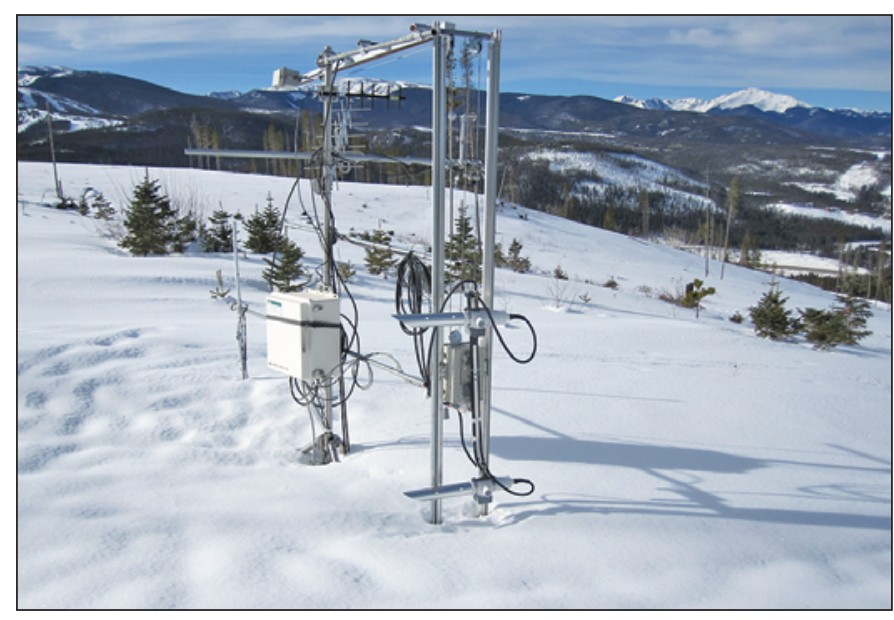

Figure 4. Meteorological and continuous sublimation monitoring station, Upper Colorado River Basin (photograph by David Clow, U.S. Geological Survey).

\section{Water-Use Information}

The USGS defines water use as the interaction of humans with the hydrologic cycle. Human water use is a major component of a regional water budget. Water-use data collected by the USGS describe water that is withdrawn from a source and delivered to a "customer" and is reported for the following categories of use: public supply, domestic, commercial, industrial, irrigation, livestock, mining, aquaculture, hydroelectric and thermoelectric power generation, and wastewater returns. The USGS has published national compilations of water-use data since 1950 (at 5-year intervals) as part of the National Water Use Information Program (Maupin and others, 2014).

Water-use data for the CRB FAS are being compiled as annual total withdrawals by source and include the water-use categories listed previously. Data are being aggregated for 8-digit Hydrologic Unit Code (HUC-8) watersheds within the Upper and Lower Colorado River Basins rather than by county/State, which is the format used for USGS national water-use compilations. Water that is withdrawn and applied within the hydrologic basin boundaries of the CRB are reported as a water use at the point where water is taken from the source. Additionally, water that is exported outside the basin boundaries ("interbasin transfers") is summarized for municipal, industrial, and irrigation uses. In order to look back at recent trends in water use in the $\mathrm{CRB}$, data are being reaggregated for HUC-8 watersheds from 1985 to 2010, in 5-year intervals, with consumptive use for thermoelectric power generation and irrigation for 1985-95, 2010, and sporadically for 2000 and 2005. These data are intended to enhance hydrologic studies by representing the effects of water use on the water budget and, therefore, water availability. Water-use compilations at this scale and number of categories is not planned to be continued into the future (fig. 5).

\section{Groundwater Discharge to Streams}

Historically, management of water resources in the CRB has focused on surface-water supplies; however, groundwater and surface water are interconnected, and groundwater discharge to streams sustains surface-water flows in much of the UCRB. In light of recent droughts and anticipated changes in climate, there is a need to understand the link between groundwater and surface water. The objective of this component of the CRB FAS is to quantify groundwater discharge to streams across the UCRB.

To estimate groundwater discharge to streams in the UCRB, methods were developed to use in-stream water-quality data, specifically the electrical conductivity (specific conductance, SC)

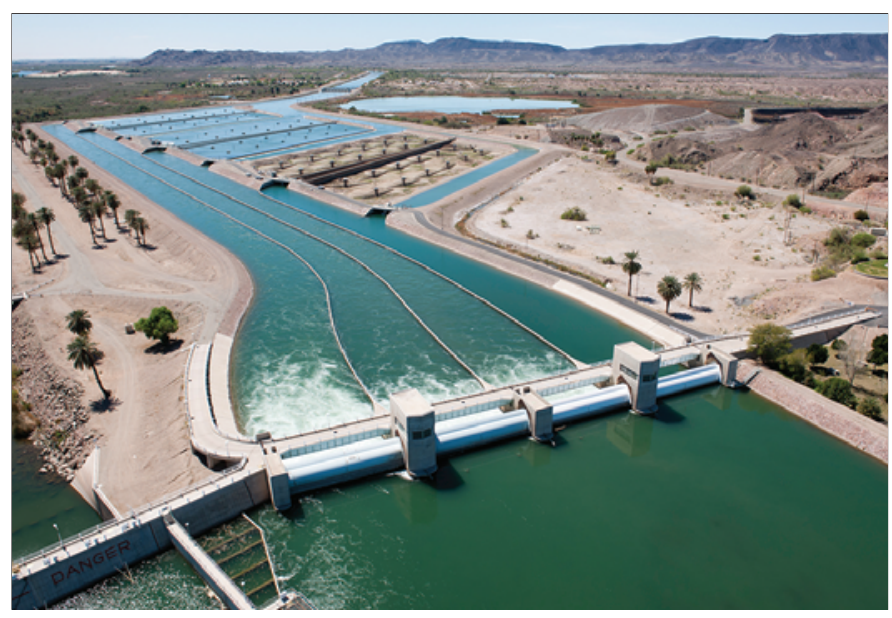

Figure 5. Colorado River diversion (water use) at the Imperial Dam, which crosses the Colorado River along the Arizona-California border near Yuma, Arizona (photograph from Bureau of Reclamation).

of stream water, to quantify the fraction of streamflow that originates as groundwater. Using this approach with SC data that were continuously measure in 14 streams and rivers in the UCRB, it was determined that, on average, $21-58$ percent of annual streamflow at these sites originates as groundwater discharge (Miller and others, 2014). For sites where only occasional measurements of $\mathrm{SC}$ (referred to as discrete data) have been made, an additional method was developed to estimate the percentage of streamflow that originates as groundwater (Miller and others, 2015). This method was applied at 229 sites in the UCRB. The results show that groundwater discharge to streams contributes an average of 48 percent of total streamflow in the UCRB, with site-specific estimates ranging from 12 to 92 percent (Rumsey and others, 2015) (fig. 6). Spatially, groundwater discharge to streams is greater in upland, mountainous areas that have greater precipitation. The last phase of the study, which is currently underway, uses the annual estimates of groundwater discharge to streams at these 229 sites as calibration data in a Spatially Referenced Regression on Watershed Attributes (SPARROW) model (Schwarz and others, 2006) to estimate groundwater discharge to streams in more than 10,000 stream reaches in the UCRB.

\section{In Closing}

The Colorado River Basin Focus Area Study developed new information on important components of the basin water budget that can be used to inform water managers and users throughout the region. This fact sheet provides an early summary of the USGS activities in the CRB as part of the USGS National Water Census Geographic Focus Area Study. The following list of references guides the reader to a more in-depth discussion on most of the information contained herein. Interested readers also are directed to the National Water Census online data portal (http://water.usgs.gov/ watercensus/) where existing data and publications can be accessed.

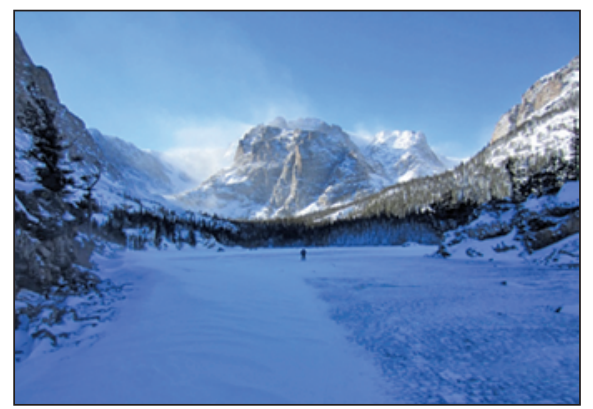

Wind-blown snow in the Rocky Mountains (photograph by David Clow, U.S. Geological Survey). 


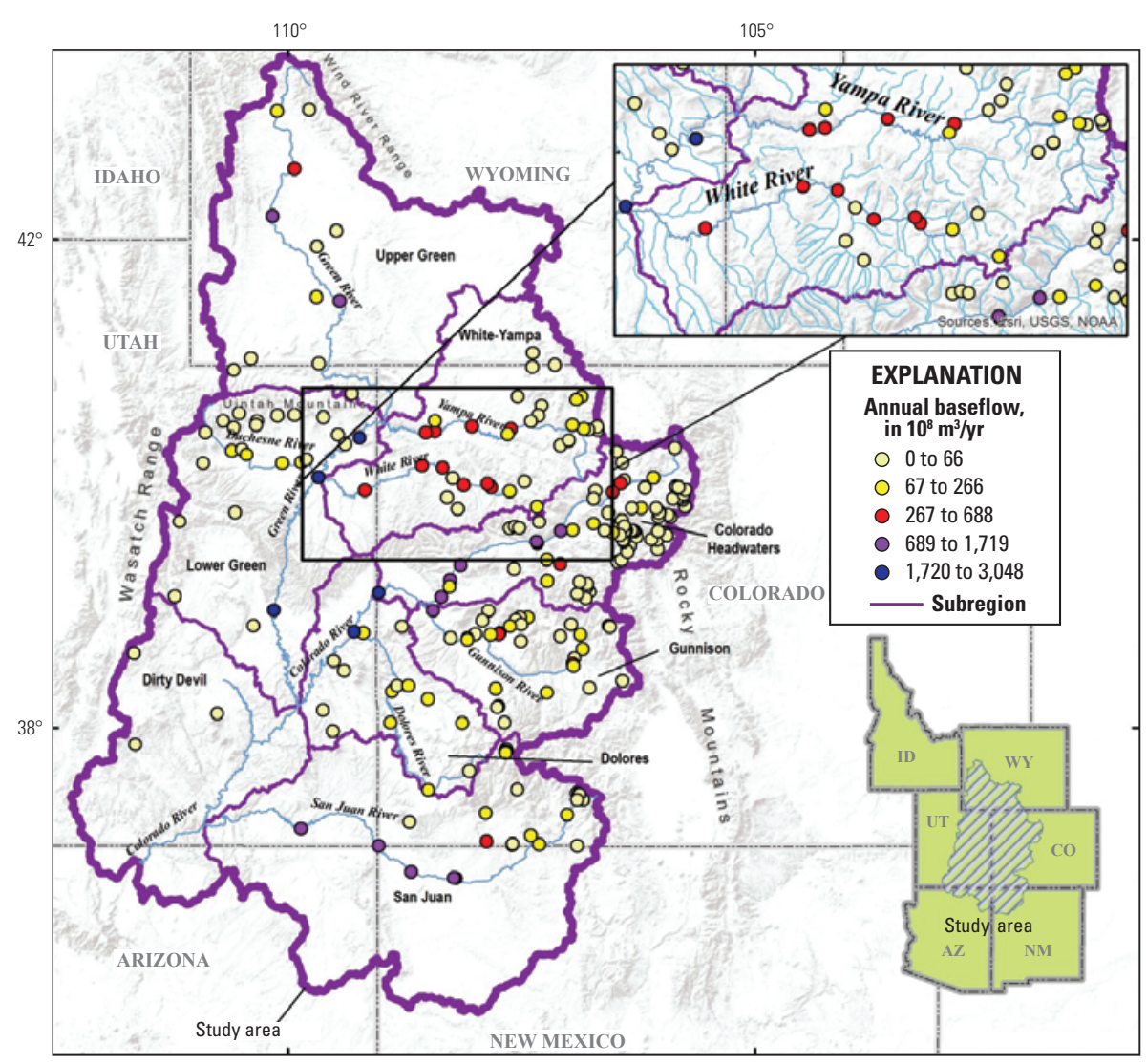

Figure 6. Estimates of annual groundwater discharge to streams (baseflow) at 229 sites in the Upper Colorado River Basin (UCRB). Groundwater discharge to streams contributes an average of 48 percent of total streamflow in the UCRB. Modified from Rumsey and others (2015). [m³/yr, cubic meters per year]

Base map sources: ESRI, USGS, NOAA

\section{References Cited}

Clow, D.W., 2010, Changes in the timing of snowmelt and streamflow in Colorado-A response to recent warming: Journal of Climate, v. 23, no. 9, p. 2293-2306. (Also available at http://dx.doi.org/10.1175/2009JCLI2951.1.)

Clow, D.W., Nanus, L., Verdin, K.L., and Schmidt, J., 2012, Evaluation of SNODAS snow depth and snow water equivalent estimates for the Colorado Rocky Mountains, U.S.A: Hydrological Processes, v. 26, no. 17, p. 2583-2591. (Also available at http://dx.doi.org/10.1002/hyp.9385.)

Clow, D.W., Williams, M.W., and Ingersoll, G.I., 2015, Influence of windblown dust on snowpack chemistry and snowmelt timing in mountains of the western U.S., in Proceedings of the 9th International Conference on Acid Deposition, October 19-23, 2015, Rochester, N.Y. (Also available at http://acidrain2015.org/Documents/AcidRain2015_Proceedings.pdf.)

Healy, R.W., Winter, T.C., LaBaugh, J.W., and Franke, O.L., 2007, Water budgets - Foundations for effective water-resources and environmental management: U.S. Geological Survey Circular 1308, 90 p. (Also available at http://pubs.usgs.gov/circ/2007/1308/.)

Maupin, M.A., Kenny, J.F., Hutson, S.S., Lovelace, J.K., Barber, N.L., and Linsey, K.S., 2014, Estimated use of water in the United States in 2010: U.S. Geological Survey Circular 1405, 56 p. (Also available at http://dx.doi.org/10.3133/cir1405.)

Miller, M.P., Johnson, H.M., Susong, D.D., and Wolock, D.M., 2015, A new approach for continuous estimation of baseflow using discrete water quality data-Method description and comparison with baseflow estimates from two existing approaches: Journal of Hydrology, v. 522, p. 203-210.

Miller, M.P., Susong, D.D., Shope, C.L., Heilweil, V.M., and Stolp, B.J., 2014, Continuous estimation of baseflow in snowmelt-dominated streams and rivers in the Upper Colorado River Basin-A chemical hydrograph separation approach: Water Resources Research, v. 50, no. 8, p. 6986-6999.

National Operational Hydrologic Remote Sensing Center, 2004, Snow Data Assimilation System (SNODAS) data products at NSIDC, ver. 1: Boulder, Colo., National Snow and Ice Data Center, accessed October 28, 2015, at http://dx.doi.org/10.7265/N5TB14TC.

Painter, T.H., Skiles, S.M., Deems, J.S., Bryant, A.C., and Landry, C.C., 2012, Dust radiative forcing in snow of the Upper Colorado River Basin-1. A 6 year record of energy balance, radiation, and dust concentrations: Water Resources Research, v. 48, no. 7. (Also available at http://dx.doi.org/10.1029/2012WR011985.)
Rumsey, C.A., Miller, M.P., Susong, D.D., Tillman, F.D., and Anning, D.W., 2015, Regional scale estimates of baseflow and factors influencing baseflow in the Upper Colorado River Basin: Journal of Hydrology-Regional Studies, v. 4, p. 91-107. (Also available at http://dx.doi.org/10.1016/ j.ejrh.2015.04.008.)

Schwarz, G.E., Hoos, A.B., Alexander, R.B., and Smith, R.A., 2006, The SPARROW surface water-quality model-Theory, application, and user documentation: U.S. Geological Survey Techniques and Methods Report, book 6, chap. B3. (Also available at http://pubs.usgs.gov/tm/2006/tm6b3/.)

Senay, G.B., Bohms, S., Singh, R.K., Gowda, P.H., Velpuri, N.M., Alemu, H., and Verdin, J.P., 2013, Operational evapotranspiration mapping using remote sensing and weather datasets - A new parameterization for the SSEB approach: Journal of the American Water Resources Association, v. 49 , no. 3 , p. $577-591$.

Singh, R.K., Senay, G.B., Velpuri, N.M., Bohms, S., Scott, R.L., and Verdin, J.P., 2014, Actual evapotranspiration (water use) assessment of the Colorado River Basin at the Landsat resolution using the Operational Simplified Surface Energy Balance model: Remote Sensing, v. 6, no. 1, p. 233-256. (Also available at http://dx.doi.org/10.3390/rs6010233.)

U.S. Geological Survey, 2007, Facing tomorrow's challenges-U.S. Geological Survey science in the decade 2007-2017: U.S. Geological Survey Circular 1309, $70 \mathrm{p}$.

Velpuri, N.M., Senay, G.B., Singh, R.K., Bohms, S., and Verdin, J.P., 2013, A comprehensive evaluation of two MODIS evapotranspiration products over the conterminous United States-Using point and gridded FLUXNET and water balance ET: Remote Sensing of Environment, v. 139, p. 35-49. (Also available at http://dx.doi.org/10.1016/j.rse.2013.07.013.)

By Breton W. Bruce, David W. Clow, Molly A. Maupin, Matthew P. Miller, Gabriel B. Senay, Graham A. Sexstone, and David D. Susong

For more information, contact

Program Coordinator

National Water Availability and Use Science Program 12201 Sunrise Valley Drive

988 National Center

Reston, VA 20192

Or visit the National Water Census Web site at

ISSN 2327-6916 (print)

http://water.usgs.gov/watercensus/
ISSN 2327-6932 (online) http://dx.doi.org/10.3133/fs20153080 